\title{
Computer-Based Technology (CBT) Assessment Implementation in a Nigerian Higher Institution and a Lecturer's Work Stories: Implication for E-Counselling
}

\author{
https://doi.org/10.3991/ijac.v12i3.11341 \\ Ifeyinwa Osegbo $(\bowtie)$ \\ Nwafor Orizu College of Education, Nsugbe, Nigeria \\ ifyosegbo@gmail.com \\ Vera Nwadinobi \\ Nnamdi Azikiwe University, Awka, Nigeria
}

\begin{abstract}
Computer-based technology (CBT) assessment is a new practice in the conduct of examinations in Nigeria but it has its problems. Many societies have accepted information technology as the way the world is moving, therefore this study aimed at investigating lecturers' perception of innovative computerbased assessment format in a Nigerian College of Education. Participants included 200 lecturers, 120 male and 80 female. The age range was between 30 and 64 years. They were randomly selected purposely from five schools in a college of education in Nigeria. The design adopted was a cross-stage mixed-model design. Oral interview, structured questionnaire and focus group discussions were used to collect data. Measured accessibility variable showed that 98 percent of lecturers have access to a computer. However, results on the knowledge requirements and usage variable revealed that many lecturers do not have adequate ability level in the use of computers, especially the chief lecturers and older lecturers. The most challenging aspect of CBT assessment was found to be the Authoring Manager in transporting the questions to Qpack. The findings of this study has implications for e-counselling and attitudinal change. Most Nigerian lecturers' ability in the usage of computers is very low even though most of them have access to computers. This could be linked to their attitude and perception towards the innovative CBT assessment which is that it is not necessary and should be discouraged. This calls for e-counselling with emphasis on CBT assessment for optimal service delivery and international best practices in Nigerian higher institutions.
\end{abstract}

Keywords - CBT assessment, lecturers, work stories, higher institutions

\section{Introduction}

[11] Described assessment as a range of activities including testing, performances, project ratings and observations. The traditional educational system is a setting whereby the teacher and the students are in the same classroom using a board and other 
instructional materials to effect teaching and learning. In recent times, information and communication technology (ICT) through e-learning has made education more flexible. Many societies have accepted information technology as the way the world is going [9]. E-learning is the use of ICT to enhance and support the teaching and learning process. Computer-based technology (CBT) assessment is a new practice in the conduct of examinations and tests in Nigeria but it has its problems, it is the use of computers to administer tests and examinations in which student's responses are electronically recorded and assessed.

Learner's assessments are very critical in any instructional programme. To this end, assessment should be based on international best practices. Technology facilitates assessment and e-assessment has been identified as a best practice [3].

Some Nigerian higher institutions in recent times have embraced CBT assessment for semester examinations and continuous assessment tests. This is partly because the paper and pencil test (PPT) as a method of writing examinations and tests which has been the usual practice for decades, seem to be phasing out in the international digital world and best practices. Also, the attendant problems of the manual method of assessment which include examination venue - capacity, cost implication of printing examination materials, delay in the release of results, examination malpractice, etc., could also be the reason for the paradigm shift. Change is the only thing that is permanent and constant. But every change is expected to bring about a positive development to the society. Technology-based assessment (CBT) provides opportunities to measure complex forms of knowledge and reasoning that is not possible to engage and assess through the traditional PPT [10]. However, despite the advantages embedded with the use of CBT and ICT in teaching and learning, and the introduction by higher institutions in Nigeria, it is still not well-accepted by some Nigerian lecturers. There is no gainsaying that information communication technology offers new measures for assessing learning that will yield rich sources of data and expand the ways in which educators understand both learning mastery, and teaching effectiveness. However, some challenges confront implementation of CBT assessment in most Nigerian institutions of higher learning. Baker-Eveleth et al in [10] observed that implementing computer exams requires a secure testing environment, one that prevents students from seeking answers by scanning their computer hard drives, instant messaging or e-mailing friends, or browsing the internet. The use of ICT for test administration in Nigerian higher institutions is geared towards changing the state of test administration, but the integration has not yet been fully utilized in the nation's higher institutions. Few authors have developed CBT applications to be used in examinations. [2] A proposed model for a computer-based test in Nigeria enforces all applicants for the Joint Admissions Matriculation Board (JAMB) examination to be subjected to an online entrance examination. The model revealed that $\mathrm{CBT}$ has the potential to eliminate some of the problems that are associated with the paper-based test. [4] A computer-based test application was also developed where tests in multiple choice formats could be taken online and graded immediately. These studies showed that CBT could help lecturers, instructors, teachers and others make examinations an easy and less cumbersome task. However, most of these applications are developed without getting the lecturers, teachers and even 
students intimated on how to go about it. This is in line with [8] who found out that secondary school teachers' computer literacy is low.

In higher institutions in Nigeria, CBT assessment has been introduced but observations have shown that most lecturers are not quite disposed to it and this has added to other problems confronting the implementation of CBT assessment in higher institutions of Nigeria. To fully implement CBT assessment for students in the higher institutions, there is a need to get the lecturers who are the facilitators of learning involved and equipped with the necessary skills and attitudes needed for the process of the new innovative CBT assessment. To this end, the present study is aimed at investigating lecturers work stories in accessibility, ability and usage of computers for CBT assessment in a Nigerian higher institution and its implication for e-counselling. To guide the study, the following research questions were raised.

- To what extent do Nigerian higher institution lecturers have access to a computer?

- Do Nigerian higher institution lecturers have the ability to use a computer?

- Do Nigerian higher institution lecturers employ ICT gadgets to enhance CBT assessment?

- What is the lecturer's perception of computer-based assessment in Nigerian higher institutions like?

\section{Methods}

The study adopted a mixed-methods research approach. Mixed method is defined as the class of research where the researcher combines qualitative and quantitative techniques into a single study. The design is suitable for the study because of the research questions which have both qualitative and quantitative questions. In justifying their perceptions participants had to express their views, opinions as well as their feelings about CBT in higher institutions in Nigeria.

The population of this study comprised all the lecturers in higher institutions in Nigeria. However, for ease of administration, one college of education was purposely selected as a case study. The participants were 200 randomly selected lecturers from the six academic schools of the institution. The sample was stratified on the basis of gender and age. There were 120 male and 80 female lecturers.

The instrument was the 'CBT Assessment Questionnaire' which consisted of two sections. It contained both the demographic information and the items/questions requiring respondent's information on their accessibility to a computer, their ability to use the computer, whether they employ CBT in assessment of their students and their perception to utilization of CBT and ICT gadgets in assessment. The instrument was validated by experts in Measurement and Evaluation to ensure validity. The reliability of the instrument was established through Cronbach alpha reliability technique with a co-efficient value of 0.75 .

The method for data collection was a combination of administered questionnaire and focus group discussion (FGDs) exercises. The content of the questionnaire was a combination of close and open-ended questions. Focus group discussions produce descriptive data about people's own written or spoken and observable behaviour. 
The data were analyzed using both quantitative and qualitative formats. Two main procedures were therefore applied in the analysis of the data so as to be in tandem with the mixed research approach adopted for the study. NCSS 2007 quantitative method of data analysis was used to analyze quantitative data collected from the closed-ended questions. (NCSS performs a variety of data analysis and presentation of functions, including statistical analysis and graphical presentation of data). Content analysis was used for the qualitative data collected. This involved sorting, categorizing and tallying the data which were mainly additional information to or justification of responses given to closed-ended questions in line with the mixed model design. Narrative presentation was done for some of the questions.

\section{$3 \quad$ Results}

The biographical characteristics of the respondents are presented before the presentation of the findings related to the problem under study.

Table 1. Distribution of Respondents on the basis of Gender and Age.

\begin{tabular}{|l|c|c|}
\hline \multicolumn{1}{|c|}{ Variables } & Frequency & Percentage \\
\hline Male & 120 & $60 \%$ \\
\hline Female & 80 & $40 \%$ \\
\hline Age & & $40 \%$ \\
\hline $30-40$ Years & 80 & $30 \%$ \\
\hline $41-45$ Years & 60 & $20 \%$ \\
\hline $46-50$ Years & 40 & $5 \%$ \\
\hline $51-60$ Years & 10 & \\
\hline
\end{tabular}

Table 1 presents the demographic characteristics of the participants in frequency count and percentage. It shows that 60 percent of the study samples are males while 40 percent are females. Figure 2 shows the respondents who fall within the $30-40$-year age bracket to constitute 40 percent of the total sample. The bar and pie charts that follow describe the demographic characteristics of the study participants. 


\section{Gender}

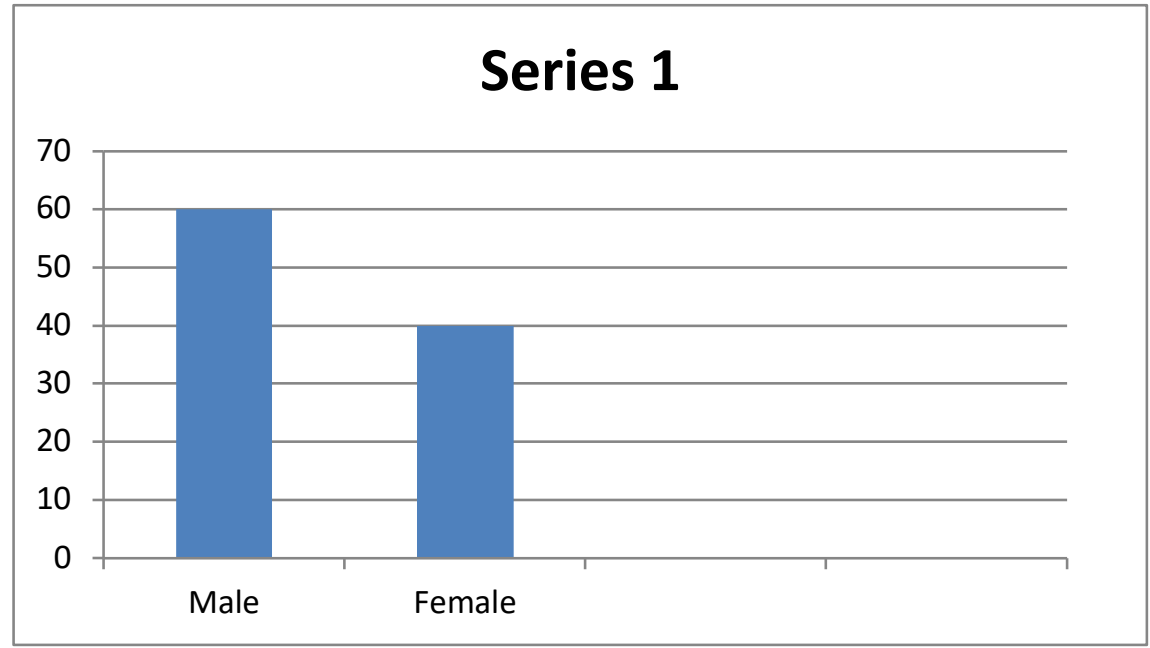

Fig. 1. Bar Chart Distribution of Participants based on Gender

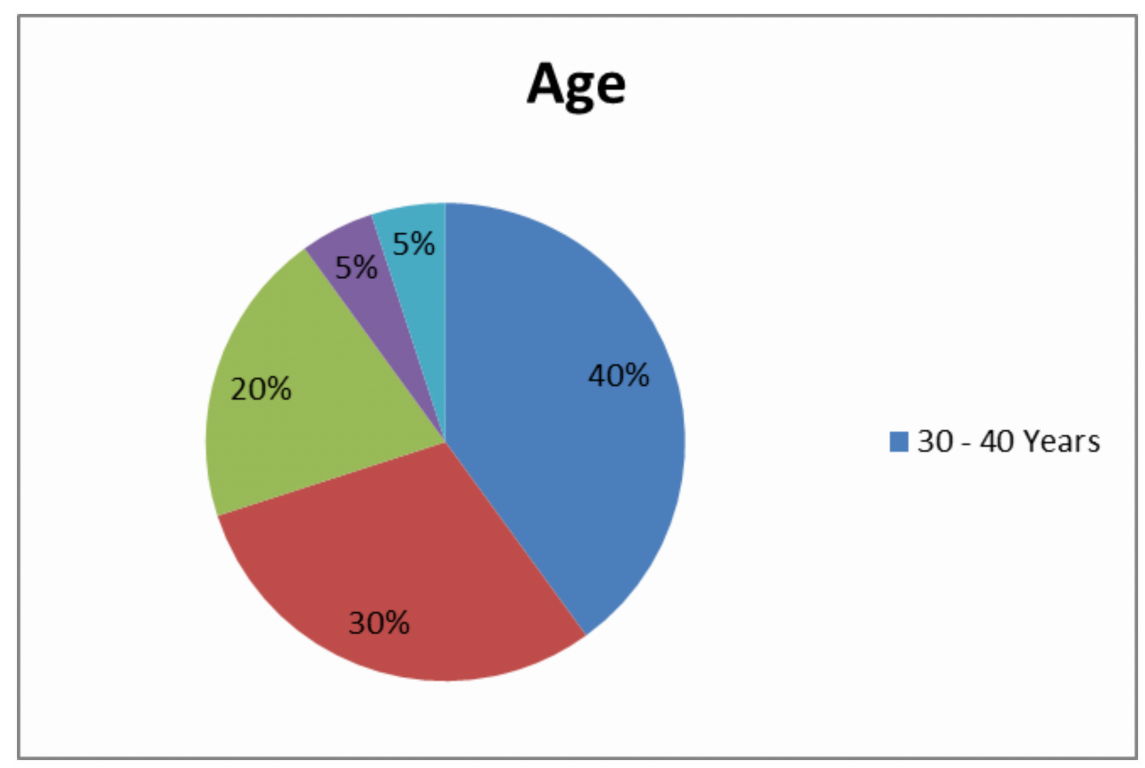

Fig. 2. Pie Chart Distribution of Respondents based on Age 
3.1 Research Question 1: Do Nigerian higher institution lecturers have access to a computer?

Table 2. Lecturers computer accessibility index shown in frequency count and percentage.

\begin{tabular}{|c|l|c|c|}
\hline S/N & What is the nature of your access to a computer? & Frequency & Percentage \\
\hline 1. & Personal computer (laptop) & 100 & $50 \%$ \\
\hline 2. & Friends & 16 & $8 \%$ \\
\hline 3. & College internet facility & 44 & $22 \%$ \\
\hline 4. & Library & 08 & $4 \%$ \\
\hline 5. & Office & 12 & $6 \%$ \\
\hline 6. & Cyber café & 16 & $8 \%$ \\
\hline 7. & None & 04 & $2 \%$ \\
\hline & Total & $\mathbf{2 0 0}$ & $\mathbf{1 0 0} \%$ \\
\hline
\end{tabular}

Table 2 presents lecturer's accessibility to a computer. From the table most of the respondents had one access or the other to a computer. Fifty percent of the respondents have access to a personal computer, 8 percent have access to their friends' computer, 22 percent have access to a college internet facility, only 4 percent have access to a computer in the library, 6 percent have access to a computer in the office while 8 percent have access to a computer in cyber cafés. Only 2 percent of the respondents said they have no access to a computer at all. Figure 3 presents the pie chart of table 2 .

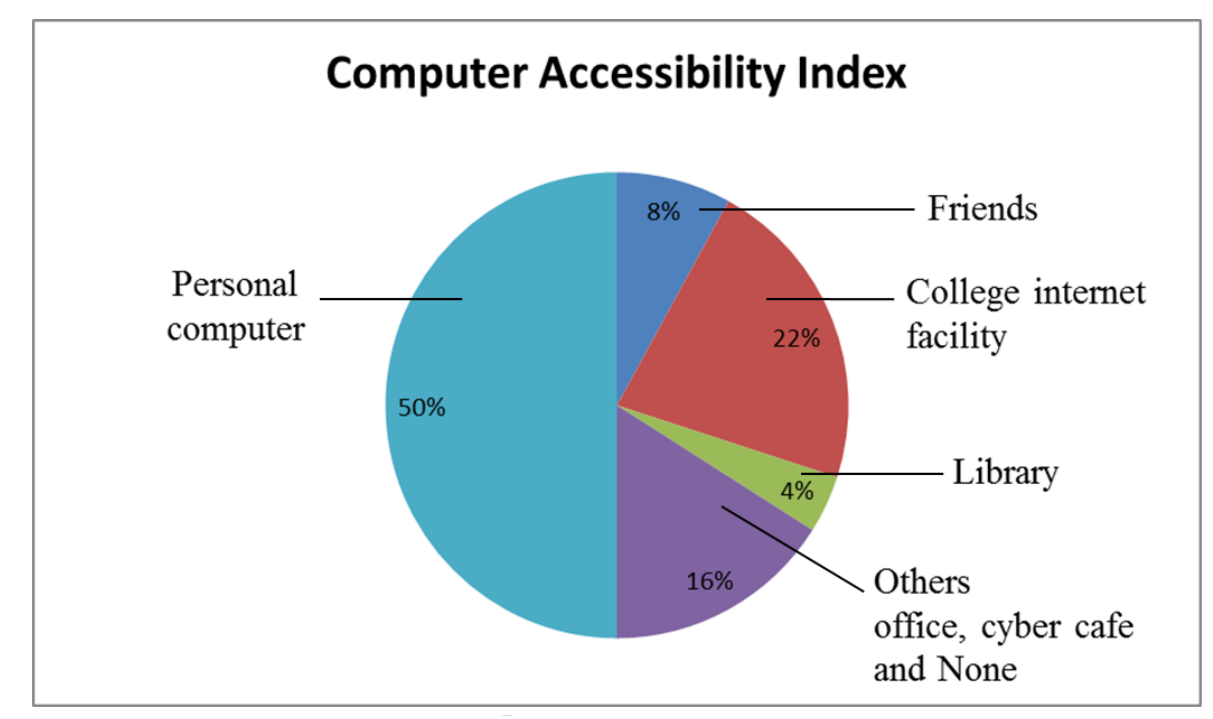

Fig. 3. Percentage Distribution of Respondents Computer Accessibility 
3.2 Research Question 2: Do Nigerian higher institution lecturers have the required ability to use a computer?

Table 3. Computer requirements and usage index in frequency count and percentage.

\begin{tabular}{|c|l|c|c|}
\hline S/N & What is your rating of your ability to use a computer? & Frequency & Percentage \\
\hline 1. & Very high & 10 & $5 \%$ \\
\hline 2. & High & 20 & $10 \%$ \\
\hline 3. & Moderate & 90 & $45 \%$ \\
\hline 4. & Low & 60 & $30 \%$ \\
\hline 5. & Very low & 20 & $10 \%$ \\
\hline & Total & 200 & $100 \%$ \\
\hline
\end{tabular}

Table 3 shows the frequency of the responses by lecturers indicating their ability in the use of a computer. Only 10 (5 percent) out of 200 respondents have very high ability in the use of a computer. Twenty (representing 10 percent) of the participants have high ability. Less than half of the total sample ( 45 percent) has moderate ability while 40 percent of the total sample has either low or very low ability. Figure 4 depicts the result in table 3 .

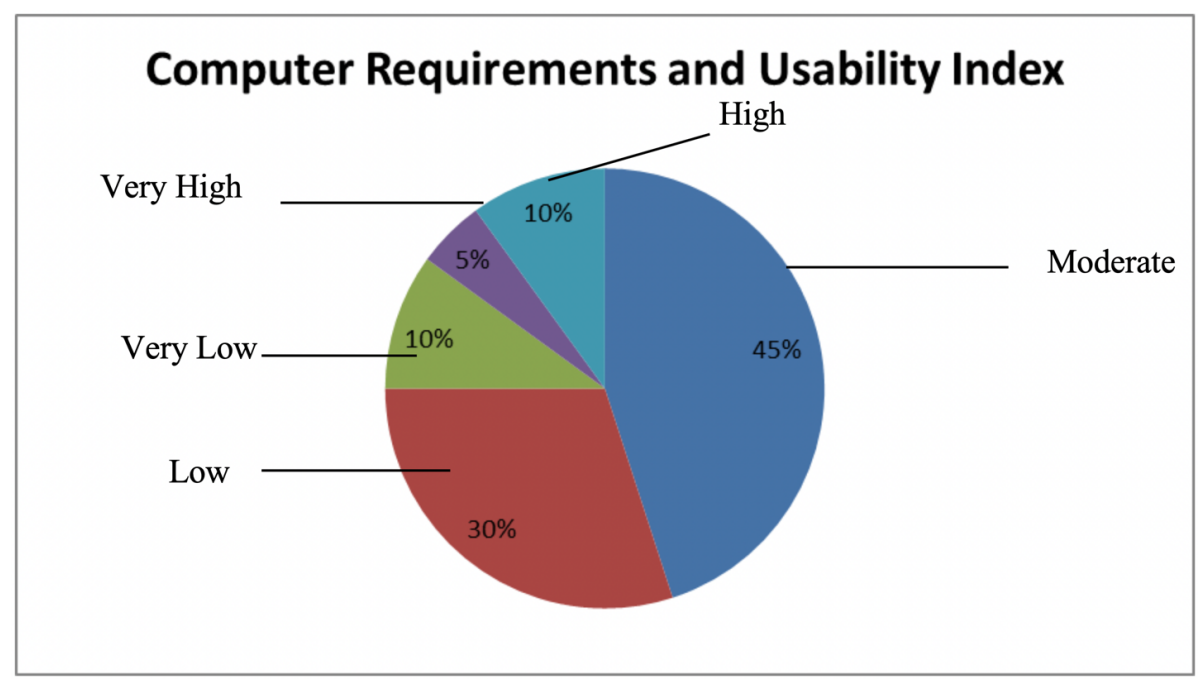

Fig. 4. Percentage of Distribution of Respondent's Computer Requirements and Usage Index. 
3.3 Research Question \#3: Do Nigerian higher institution lecturers employ ICT gadgets to enhance CBT assessment?

Table 4. Lecturers 'employment of ICT gadgets in CBT assessment

\begin{tabular}{|c|l|c|c|}
\hline S/N & Do you normally employ ICT or engage in CBT assessment \\
of your students? & Frequency & Percentage \\
\hline 1. & Yes & 40 & $20 \%$ \\
\hline 2. & No & 160 & $80 \%$ \\
\hline & Total & 200 & $100 \%$ \\
\hline
\end{tabular}

The table shows that 80 percent of the lecturers do not make use of ICT gadgets which are used for CBT assessment. Only 40 participants (representing 20 percent of the sample) agreed to using ICT gadgets in assessment. Figure 5 further demonstrates the result.

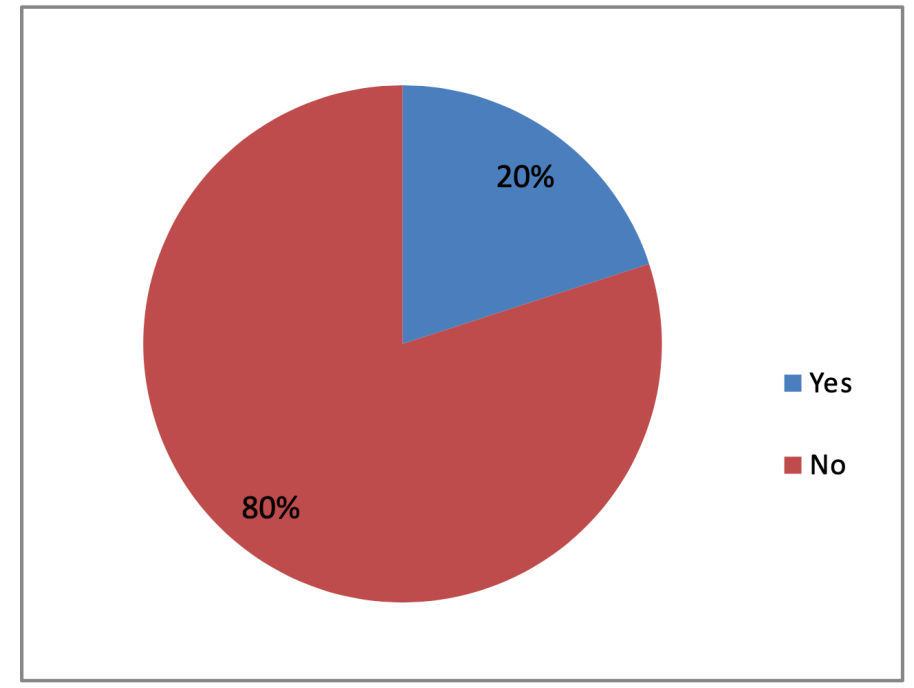

Fig. 5. Percentage Distribution of Lecturers' Employment of ICT Gadget in Assessment.

\subsection{Research Question 4: What is the lecturers' perception of computer-based technology assessment in Nigerian higher institutions like?}

Focus group discussions and interviews revealed diverse opinions concerning computer-based assessment in Nigerian higher institutions. Some of the lecturers, especially those in the School of Arts and Social Sciences, Languages, and Early Childhood Care and Education and chief lecturers, were of the opinion that computer-based technology assessment is not very relevant to their programmes of instruction while others are constrained due to their own personal challenges in ICT literacy. The following excerpts represent a summary of ideas and opinions of the respondents: 
- A participant respondent remarked: "CBT assessment does not encourage initiative, abstract thinking and creativity. I do not believe in it and I have never subscribed to it."

- Another respondent said: "CBT promotes guess work among the students, thereby making them get away with unmerited marks."

- The third respondent complained thus: "Computer-based technology assessment seems good but the difficulty in the use of authoring manager in exporting the questions to Qpack is my problem."

- Yet another respondent added: "I am already used to paper and pen assessment, computer-based technology assessment is an unnecessary stress."

- Other respondents had the following to say:

- "To draw the questions poses a lot of challenges as it is time consuming and stressful."

- "Computer-based assessment limits practical knowledge of the subject matter."

- "CBT assessment is fast and machine-scored, thereby reducing lecturers' stress in marking."

- "I am almost out of the system and we were not trained in CBT assessment, so I think the new breed lecturers should go ahead with computer-based assessment."

- "Many of our students are not even computer literate, so e-assessment will disadvantage some of them."

- "I think it is good for quizzes but should not be used for full-scale examination which requires comprehensive writing. Also, it is not a very good way of testing courses involving calculations."

- "Our epileptic power supply in Nigeria does not help matters while using e-assessment. CBT assessment encounters a lot of problems so I do not encourage it all. It is better we continue with paper and pencil test."

- "How can I support CBT assessment when after the results are collated, the officials at the college portal tampers with my result. In fact, the system is fraught with many problems and should be scrapped."

\section{Discussion}

The use of information and communication technology for registering and administering examinations help in attaining efficiency and error-free results and computations. This study revealed that 98 percent of lecturers have access to a computer. The results further showed that only 10 (5 percent) of the sample have very high ability in the use of a computer including the use of Authoring Manager in transporting questions to Qpack for the purpose of e-assessment. Ten percent have high ability, while 45 percent have moderate ability. Thirty percent have low ability while the remaining 10 percent have very low ability in the use of a computer. This finding is not encouraging bearing in mind the importance of computer literacy in a globalised world. This finding aligned with [12] whose study revealed a general low use of ICT by senior secondary school teachers for instructional delivery. 
This is not surprising as some of the respondents' attitude and perception shows that they are not favorably disposed toward CBT assessment. To some of them, e-assessment is not necessary and should be discouraged, since to some of them it does not test knowledge in comprehensive and integrated form. To some of them, it is not a true test of knowledge since some students get unmerited scores due to guess work. The most challenging aspect of CBT assessment in Nigerian higher institutions was found to be the use of Authoring Manager in transporting the questions to Qpack. The responses of male and female lecturers did not differ much on their ability and perceptions towards computer-based technology assessment. This finding is in disagreement with findings of [6], which revealed that male teachers are more ICT compliant than female teachers, older lecturers do not consider themselves capable of using the computer as responded by some of the participants. [6] Also supports this finding with their earlier findings which indicated that age poses a barrier on the effective use of ICT devices by the teachers.

\section{$5 \quad$ Implications for E-Counselling}

Assessment in schools is geared towards finding out how much the student has acquired in terms of learning skills. E-counselling is the use of technology such as the internet, telephone, e-mail, test messages, WhatsApp, etc., in delivering service to clients. Many societies have accepted information technology as the way the world is going [9].

The practice of computer-based technology assessment is also becoming popular in Nigerian higher institutions. School counselling is also expected to go online so as to meet the demands of the institution's community, especially the lecturers. To this end the result of the present study has implications for counselling and for e-counselling practice in the nation's higher institutions. Assessment and evaluation of students using CBT by lecturers who are not ICT compliant may pose a significant danger both on the student's performance and the lecturers' job satisfaction and adjustment. The lecturers need at this time to be exposed to ICT and CBT assessment skills so that they can apply such skills when administering and scoring computer-based technology examinations and tests.

The institution counsellor needs to work on the lecturer's perception and attitude, especially the older lecturers and chief lecturers who see CBT assessment as unnecessary and meant for the new breed lecturers, if it will be considered in conducting examinations at all. The counsellor can do this by organizing occasional staff forums in the colleges where an expert in computer technology and CBT assessment will be invited to train the lecturers on the skills of conducting CBT examinations for their students.

E-counselling is a viable option for reaching out to clients with stressful conditions. Since most of the respondents reported that CBT assessment is stressful and should be scrapped, there is need to reach out to them for help. [1]) seemed confident about the efficacy of the modality of e-counselling when they wrote that it has been found to be effective in treating a range of psychological disorders and stressful conditions. There is need for attitude change and treatment of phobia towards CBT assessment and this 
condition requires cognitive restructuring which can only be achieved through e-cognitive behavioural therapy. The counsellor can set up free social networking accounts with social networking and social bookmarking sites such as Facebook, LinkedIn, Twitter, WhatsApp and Digg as a great way to promote staff counselling in the school. These sites, which have now become central to net culture, will make it easy to post information that others might find interesting and equally easy for others to share what the counsellor posted. E-counselling seems to be the most functional since school programmes may not allow the lecturers the opportunity to go to the counsellor, secondly most of them rarely go for counselling. Therefore, through e-counselling the counsellor will be able to inform lecturers about the advantages and ease of using CBT assessment on their students. To catch up with the new trend in assessment (CBT), lecturers in Nigeria need to be ICT compliant so that it will enhance their practices.

The current lack of policy framework for ICT and CBT implementation in higher education systems in Nigeria shows that higher education is not equipped to keep up with the ICT revolution currently sweeping the world. For Africa, and Nigeria in particular, to take pride of place in the committee of nations and in the scheme of things, CBT assessment must be incorporated in the curricular of higher education in the region. [7] Submits that electronic supported assessment or e-assessment is a field of growing importance but has yet to make a significant impact in higher institutions in the Nigerian education sector. However, with e-counselling on the advantages of CBT assessment and the ease of practice for Nigerian lecturers, negative stories on the practice will definitely change to positive.

\section{Recommendations}

The following recommendations are hereby made based on the findings:

- Adequate funding of educational institutions by the government of the day is necessary so that lecturers could be sent on vacation courses from time to time on computer usage and its application to CBT assessment. Therefore UNESCO's 20 percent budget stipulation for education of the total annual budget should be implemented by the Nigerian government.

- Public-private partnership initiatives should be vigorously pursued by various higher educational institutions to boost CBT assessment and e-learning capacity in terms of human and material resources.

- In the recruitment stage, higher institution management should make it mandatory to take lecturers and staff with ICT knowledge so that conducting CBT assessment will not be a problem to such lecturers in future.

- The college guidance counsellor in collaboration with computer science departments in higher institutions should be made to organize CBT workshops once a semester to get the students and staff ready for CBT assessments in both class tests and examinations. 


\section{$7 \quad$ Acknowledgement}

We, Ifeyinwa and Vera, hereby acknowledge the benevolence of the ICELW team in allowing us to send our paper even after the closing date has elapsed. Thanks very much.

\section{References}

[1] Abbott, J.A.M., Klein, B., \& Ciechomski, L. (2008). Best practices in online therapy. Journal of Technology in Human Services, 26, 360 - 375. https://doi.org/10.108 0/15228830802097257

[2] Ayo, C.K., Akinyemi, I., Adebiyi, A.A. \& Ekong, U.O. (2007). The prospects of e-examination implementation in Nigeria. Turkish Online Journal of Distance Education, 84 (10), $125-135$.

[3] Buzzetto-More, N. \& Alade, A.J. (2006). Best practices in e-assessment. Journal of Information Technology Education, 5. Available online at www.v5p251-269Buzzeto 152(1).pdf. https://doi.org/10.28945/246

[4] Durojaye, D.S. \& Omotehinwa, T.O. (2013). Computer Based Test: Security and Result Integrity. International Journal of Computer and Information Technology, 2, 3379 - 07642.

[5] Esere, M.O. \& Idowu, A.I. (2012). Computer Accessibility, usage and lecturers' perception in a Nigerian university: implication for attitudinal change. The counsellor 31, (1), 1-13.

[6] Ogazie, C.A., Aghadinazu, R.E. \& Ajoku, M.U. (2017). Assessment of Teachers effectiveness on the use of information and communication technology in selected private secondary schools in Imo State, Nigeria. The counselor 36 (2), 222 - 232.

[7] Okonkwo, C.A. (2010). Using e-assessment to enhance the operational efficiencies of the national open university of Nigeria. Being text of a paper presented at the 28th Annual Conference of Association for Educational Assessment in Africa held in Abuja between 3rd to 8th October, 2010.

[8] Olagunju, A.M. (2003). An investigation into teachers' awareness and extent of utilization of information and communication technology for effective science education. Nigerian journal of computer literacy. 4 (1), $82-100$.

[9] Onuora-Ogunu, A. \& Nyuykonge, C. (2010). The influence of ICT on indigenous cultures and societies. In N. Ekeanyanwu \& C. Okeke (Eds.), Indigenous societies and cultural globalization in the 21st century. Mauritius: VDM Publishing House Ltd.

[10] Onyibe, C.O., Nwachi-Ikpo, J.O. \& Abdulhajim, A.A. (2015). Computer Based Testing Technique in Nigeria: prospects and Challenges. Journal of Information Engineering and Applications. 5(10), $17-21$.

[11] Orlich, C., Harder, G., Callahan, B. \& Gibson, E. (2004). Teaching strategies: A guide to better instruction. New York: Houghton Mifflin.

[12] Terhemba, G.A., Umaru, A. \& Bintu, M. (2016). Assessment of senior secondary school teachers' skills in using ICT for instructional delivery for National Integration in Ibadan Metropolis, Nigeria. The counsellor 36 ( $1 \& 2), 18-26$. 


\section{Authors}

Dr. Ifeyinwa Osegbo, Ph.D. is a Chief Lecturer and the current Provost, of Nwafor Orizu College of Education Nsugbe, PMB 1734 Onitsha Anambra State, Nigeria, ifyosegbo@gmail.com.

Vera Nwadinobi, Ph.D. was with Nwafor Orizu College of Education in the Department of Educational Psychology/Guidance \& Counselling, PMB 1734, Onitsha Anambra State Nigeria. She was both a Principal Lecturer and the Director, Center for Continuing Education in the college. She is currently a Senior Lecturer in the Department of Guidance and Counselling, Faculty of Education, Nnamdi Azikiwe University Awka, Anambra State, kiru92007@gmail.com.

This article is a revised version of a paper presented at the International Conference on E-Learning in the Workplace 2019 (ICELW 2019), held in June 2019, at Columbia University in New York, NY, USA. Article submitted 2019-07-20. Resubmitted 2019-09-09. Final acceptance 2019-09-18. Final version published as submitted by the authors. 